\title{
The effectiveness of traditional Japanese medicine Goshajinkigan in irradiation- induced aspermatogenesis in mice
}

Kumpei Takahashi ${ }^{1 \dagger}$, Kenta Nagahori ${ }^{1 \dagger}$, Ning Qu ${ }^{1,2^{*+}}$ (D), Miyuki Kuramasu ${ }^{1}$, Yoshie Hirayanagi ${ }^{1}$, Shogo Hayashi ${ }^{1}$, Yuki Ogawa' ${ }^{1}$, Naoyuki Hatayama ${ }^{3}$, Hayato Terayama², Kaori Suyama ${ }^{2}$, Shuichi Hirai ${ }^{3}$, Kou Sakabe ${ }^{2}$ and Masahiro Itoh ${ }^{1}$

\begin{abstract}
Background: Infertility and gonadal dysfunction are well known side-effects by cancer treatment in males. In particularly, chemotherapy and radiotherapy induced testicular damage, resulting in prolonged azoospermia. However, information regarding therapeutics to treat spermatogenesis disturbance after cancer treatment is scarce. Recently, we demonstrated that Goshajinkigan, a traditional Japanese medicine, can completely rescue severe busulfan-induced aspermatogenesis in mice. In this study, we aimed to detect the effects of Goshajinkigan on aspermatogenesis after irradiation.
\end{abstract}

Methods: This is animal research about the effects of traditional Japanese medicine on infertility after cancer treatment. C57BL/6 J male mice received total body irradiation (TBI: a single dose of 6Gy) at 4 weeks of age and after 60 days were reared a Goshajinkigan (TJ107)-containing or TJ107-free control diet from day 60 to day 120. Then, two untreated females were mated with a single male from each experimental group. On day 60, 120 and 150, respectively, the sets of testes and epididymis of the mice in each group after deep anesthetization were removed for histological and cytological examinations.

Results: Histological and histopathological data showed that 6Gy TBI treatment decreased the fertility rate $(4 / 10)$ in the control diet group; in contrast, in the TJ107-diet group, the fertility rate was 10/10 ( $p<0.05$ vs. 6Gy group). Supplementation with TJ107 was found to rescue the disrupted inter-Sertoli tight junctions via the normalization of claudin11, occludin, and ZO-1 expression and reduce serum anti-germ cell autoantibodies.

Conclusions: These findings show the therapeutic effect on TBI-induced aspermatogenesis and the recovering disrupted gonadal functions by supplementation with TJ107.

Keywords: Traditional Japanese medicine, Aspermatogenesis, Irradiation, Anti-sperm antibody; Sertoli tight junctions

\footnotetext{
* Correspondence: quning@tokyo-med.ac.jp; quning@tokai.ac.jp

${ }^{\dagger}$ Kumpei Takahashi, Kenta Nagahori and Ning Qu contributed equally to this work.

${ }^{1}$ Department of Anatomy, Tokyo Medical University, Tokyo 160-8402, Japan

${ }^{2}$ Department of Anatomy, Division of Basic Medical Science, Tokai University

School of Medicine, Kanagawa 259-1193, Japan

Full list of author information is available at the end of the article
}

(c) The Author(s). 2019 Open Access This article is distributed under the terms of the Creative Commons Attribution 4.0 International License (http://creativecommons.org/licenses/by/4.0/), which permits unrestricted use, distribution, and reproduction in any medium, provided you give appropriate credit to the original author(s) and the source, provide a link to the Creative Commons license, and indicate if changes were made. The Creative Commons Public Domain Dedication waiver (http://creativecommons.org/publicdomain/zero/1.0/) applies to the data made available in this article, unless otherwise stated. 


\section{Background}

Chemotherapy and radiotherapy are commonly used for cancer treatment, but side effects include temporary or permanent infertility. A known fact is that among the most radiosensitive organs testis is one of them and patients receiving 1.4-2.6 Gy direct testicular irradiation the spermatogenesis cannot be recovered [1]. Gonadal toxicity is associated with total body irradiation (TBI) which is often used as conditioning for transplantation of bone marrow. Around $99.5 \%$ of men as reported by previous studies experience permanent infertility who receive12Gy TBI [2] and decrease in spermatogenesis in the seminiferous tubules of mice is caused by lower TBI doses as 5-6 Gy [3, 4]. Mechanism reported through previous studies for infertility in irradiated rodent testes is germ cell-apoptosis [5-7]. Lipid peroxidation in the cellular membrane is caused by the generation of reactive oxygen species (ROS) which causes deleterious effects of irradiation in biological systems and thereby causing DNA damage in immature germ cells $[8,9]$. Some studies reported that suppressed oxidative stress or downregulate the increased amount of ROS can replace testicular function in experimental animal models [10-12]. Additionally, in three-month-old rats activation of caspase-3, concomitant with increased expression of caspase- 8 and decreased expression of caspase- 9 induces germ cell-apoptosis [7].

Young and long-term cancer survivors are increasing as the results of early diagnosis and successfully anticancer treatments. Therefore, the strategy for disease management has subsequently changed from cure at any cost to that the quality of life became increasingly important. Currently, the most effective and established avenue of reserving fertility in young cancer survivors, such as the cryopreservation and transplantation of gonadal tissue, are still experimental [13-15]. Therefore, many experiments including hormonal treatment [16-18] and vitamin treatment $[19,20]$ have been conducted to develop methods to prevent or cure testicular damage after cancer treatment. However, effective treatment has not been established and male infertility after radiotherapy is now an intractable disease.

To increase testosterone levels and improve fertility in recent time, herbal medicines have been proposed [2124 ] and number of herbs have shown positive effects on the improvement of semen parameters [25, 26]. Furthermore, synergistic effects and multiple biological functions of polyherbal formulation are of vast advantages over single herbal formulation. Goshajinkigan (TJ107), is an herbal medicine composed of 10 herbal drugs and widely used to treat lower urinary tract symptoms, numbness, lower back pain, and chemotherapy-induced neuropathy in Japan [27-30]. Indeed, the therapeutic mechanism of TJ107 have been well investigated in neuropathic pain and the studies demonstrated that TJ107 can improve mitochondrial function and can decrease the expression of tumor necrosis factor- $\alpha$ (TNF $\alpha$ ) which is a principal mediator in pro-inflammatory processes cytokine in muscle [31, 32]. Furthermore, component elements of TJ107 such as Rehmannia Root, Cornus Fruit, Plantago Seed, Moutan Bark, and Cinnamon Bark have been reported the antiinflammatory effects preciously [33-38]. The exact criteria for its use have not been established yet as the molecular mechanism of TJ107 remains unclear. Recently, we found that TJ107 can completely restore aspermatogenesis after busulfan treatment in mice [39]. Administering TJ107 can increase the germ cellproliferation and normalize germ cell-apoptosis, such as the expressions of apoptotic-genes of Fas and Caspase8 in busulfan-treated mice [28]. The aim of this study was to determine the effects of TJ107 on recover spermatogenesis after irradiation treatment in mice and to develop an effective method to minimize or reverse the gonadal toxicity associated with cancer treatment.

\section{Methodology \\ Animals}

Male C57BL/6j mice (4-week-old, weighting 16-20 g) were purchased from SLC (Shizuoka, Japan) and maintained in the Laboratory Animal Center of Tokyo Medical University. Animals were housed at $22-24{ }^{\circ} \mathrm{C}$ with $50-60 \%$ relative humidity and a 12 -h light-dark cycle.

\section{Preparation TJ107 diet}

As per the method described previously, the diet for TJ107 was prepared [39]. TJ107 (extract granules in powdered form; No. 2120107030 and 2,130,107,030) was manufactured by Tsumura \& Co. (Tokyo, Japan) according to Japanese and International manufacturing guidelines. The constituents of TJ107 are listed in Table 1. Briefly, the TJ107 diet was prepared as mouse standard diet (Oriental Yeast Co., Ltd. (Tokyo, Japan); 23.1\% crude protein $[\mathrm{w} / \mathrm{w}], 5.1 \%$ crude fat, $5.8 \%$ crude ash, $2.8 \%$ crude fiber, and $55.3 \%$ nitrogen-free extract and mineral mixture) containing 5.4\% (w/w) TJ107 extract.

\section{Experiment design}

Mice were irradiated with 6Gy using a 60Co gamma ray unit (MBR-1520A-TWZ; HITACHI KE Systems Ltd., Tokyo, Japan). A single dose of TBI was administered without anesthesia.

The division of the experimental mice was into 4 groups as: Group A (normal male mice fed a standard diet to day $120=$ control group; $n=35$ ), Group B (normal male mice fed a standard diet to day 60 and then fed a TJ107-diet to day $120=$ TJ107 group; $\mathrm{n}=35$ ), 
Table 1 Constituents in $7.5 \mathrm{~g}$ of TJ107 (JP: The Japanese Pharmacopoeia)

\begin{tabular}{lll}
\hline Herbs & Scientific names & weight \\
\hline JP Rehmannia Root & (Rehmannia glutinosa Liboschitz) & $5.0 \mathrm{~g}$ \\
JP Achyranthes Root & (Achyranthes bidentage Blume) & $3.0 \mathrm{~g}$ \\
JP Cornus Fruit & (Cornus officinalis Sieb. et Zucc.) & $3.0 \mathrm{~g}$ \\
JP Dioscorea Rhizome & (Dioscorea batatas Decaisne) & $3.0 \mathrm{~g}$ \\
JP Plantago Seed & (Plantago asiatica) & $3.0 \mathrm{~g}$ \\
JP Alisma Rhizome & (Alisma orientale Juzep) & $3.0 \mathrm{~g}$ \\
JP Poria Sclerotium & (Poria cocos Wolf) & $3.0 \mathrm{~g}$ \\
JP Moutan Bark & (Paeonia suffruticosa Andrews) & $3.0 \mathrm{~g}$ \\
JP Cinnamon Bark & (Cinnamomum cassia Blume) & $1.0 \mathrm{~g}$ \\
JP Powdered Processed & (Aconitum carmichaelii Debeaux) & $1.0 \mathrm{~g}$ \\
Aconite Root & & \\
\hline
\end{tabular}

Group C (male mice receiving a single 6Gy dose of TBI and fed a standard diet to day $120=6$ Gy group; $n=35$ ), and Group D (male mice receiving a single 6Gy TBI dose and fed a standard diet to day 60 , and then fed a TJ107-diet to day $120=6 \mathrm{~Gy}+\mathrm{TJ} 107$ group; $n=35$ ). Figure 1 shows the time schedule of treatment applied to the mice in each group. All of mice were offered a standard laboratory water. The general conditions including food intake and body weight were recorded for all mice at 10-day intervals from day 60 to day 120 . As per the guidelines of the National Institutes of Health, all the experimental protocols in the present study were carried and were approved by the Tokyo Medical University Animal Committee (Animal ethics approval No. S-27001).

On day 60 , mice in each group $(n=5)$, respectively, were terminated individually by deeply anesthetized with pentobarbital ( $65 \mathrm{mg} / \mathrm{kg}$ body weight) [39-42] followed by cardiac puncture for blood collection. Serum was separated by centrifugation and the serum samples from individual mice were stored at $-80{ }^{\circ} \mathrm{C}$ until used. The testes were removed for gravimetry for histological examination and epididymides were removed for epididymal spermatozoa counts.

The mice were cross-mated on day 120 from each group $(n=5)$ with untreated female C57BL/6 J mice (810 weeks of age; SLC, Shizuoka, Japan) at a ratio of 1:2 (male-to-female) in a cage until day 150, to assess in vivo fertilization, after which the fertility rate was determined for each group. Simultaneously, the remaining mice from each group $(n=20)$ were terminated individually on day 120 by anesthetized with $65 \mathrm{mg} / \mathrm{kg}$ body weight pentobarbital followed by cardiac puncture for blood collection. Serum was separated by centrifugation and the serum samples from individual mice were stored at $-80^{\circ} \mathrm{C}$ until used. The testes and epididymides were immediately removed for histological and cytological examinations.

\section{Histological examination and histopathological assessment of testis}

The testes of mice $(n=5)$ in each group were fixed with Bouin's solution and embedded in plastic in whole (Technovit7100; Kulzer \& Co., Wehrheim, Germany). Sections $(5 \mu \mathrm{m})$ were obtained at $15-20 \mu \mathrm{m}$ intervals and stained with Gill hematoxylin and 2\% eosin Y (Muto PC, Tokyo, Japan) for histological examination by light microscopy observation.

The testes of mice $(n=5)$ of each group were placed in OCT compound (Miles Laboratories, Naperville, IL, USA) and stored at $-80^{\circ} \mathrm{C}$. Sections of $6 \mu \mathrm{m}$ were incubated for 20 min with Block Ace (Yukijirushi, Hokkaido, Japan) at room temperature (RT) and then incubated with rabbit anti-mouse Ki67 monoclonal antibodies (Abcam, Cambridge, United Kingdom; 1:1000 dilution) for $2 \mathrm{~h}$. After washing the sections were incubated for $30 \mathrm{~min}$ with goat anti-rabbit IgG (Vector, Burlingame, CA, USA). Vectastain Elite $A B C$ Reagent (Vector Laboratories, CA, USA) with $0.05 \%$ 3,3'-

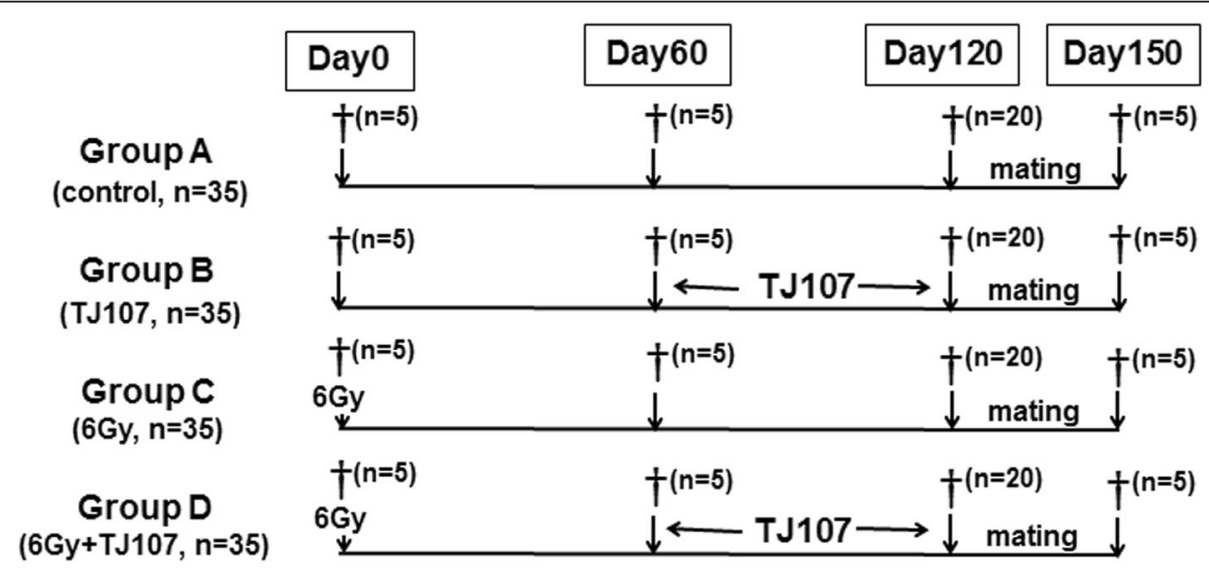

Fig. 1 Application of treatment as per the time schedule to the mice in each group 
diaminobenzidine-4HCl (DAB, Nickel Solution) and $0.01 \% \mathrm{H}_{2} \mathrm{O}_{2}$ as the chromogen was used to visualize proliferation cells.

To investigate germ cell-apoptosis, TUNEL was performed pursuant the protocol described previously [43]. Paraffin sections (5-6 um) from mice of each group $(\mathrm{n}=5)$ were cut onto silane-coated glass slides, dewaxed with toluene, and rehydrated in an ethanol series. The sections were treated with $5 \mu \mathrm{g} / \mathrm{ml}$ of proteinase $\mathrm{K}$ in PBS at $37^{\circ} \mathrm{C}$ for $15 \mathrm{~min}$ after washing with PBS. Then the sections were rinsed once with deionized distilled water and the commercially available kit (Apop Tag Plus Peroxidase In Situ Apoptosis Detection Kit; Serologicals Corporation, NY, USA) was used for detection of the 3'$\mathrm{OH}$ end of DNA. The sections were treated with 3\% $\mathrm{H}_{2} \mathrm{O}_{2}$ in PBS for $5 \mathrm{~min}$ at room temperature to block endogenous peroxidase activity. The sections were incubated with a mixture of terminal deoxynucleotidyl transferase (TdT) and digoxigenin-labelled dideoxy nucleotide in a humidified chamber at $37^{\circ} \mathrm{C}$ for $1 \mathrm{~h}$. After reaction with stop buffer for $10 \mathrm{~min}$, the sections were incubated with an anti-digoxigenin peroxidase conjugate for $30 \mathrm{~min}$. Peroxidase activity was detected by exposing the sections to a solution containing $0.05 \%$ DAB.

\section{Detection of serum anti-germ cell antibodies}

For the detection of serum anti-germ cell antibodies, normal testes from normal 8-week-old mice were put in OCT compound (Miles Laboratories, IL, USA) and then frozen in liquid nitrogen and stored at $-80^{\circ} \mathrm{C}$ until use. Sections of $6 \mu \mathrm{m}$ were cut with a cryostat (CM1900; Leica, Wetzlar, Germany), dried in air, fixed in $95 \%$ ethanol for $10 \mathrm{~min}$ at $-20{ }^{\circ} \mathrm{C}$, rinsed in PBS, and then incubated with 50-fold serial dilutions of the collected serum samples from experimental mice of each group $(n=10)$ for $60 \mathrm{~min}$ at RT. After rinsing in PBS, the cryostat sections were incubated for $60 \mathrm{~min}$ with HRP-conjugated goat anti-mouse IgG (ZyMax, CA, USA.; 1:500 dilution) at RT. After washing with PBS, the HRP-binding sites were detected with $0.05 \% \mathrm{DAB}$ and $0.01 \% \mathrm{H}_{2} \mathrm{O}_{2}$.

\section{Real-time RT-PCR analysis of mRNA expression in testis}

The testes from mice $(n=5)$ in four groups were examined. Real-time RT-PCR was performed according to the method described previously [39]. Total RNA was purified from each fresh testis sample using TRIZOL reagent (Invitrogen Corp., Carlabad, CA) according to the manufacturer's protocol, and its concentration was calculated from the extinction at $260 \mathrm{~nm}$, as determined spectrophotometrically. For the first-strand cDNA synthesis, $10 \mu \mathrm{g}$ of total RNA was reverse-transcribed with a High Capacity cDNA Archive Kit (PE Applied Biosystems, Foster City, CA, USA) according to the standard protocol. Subsequently, 3 ng of cDNA was amplified by 40 cycles of polymerase chain reaction (PCR) to measure Ki67, Fas, FasL, caspase8, claudin3, claudin11, occludin, ZO1, ZO2, and GAPDH, real-time fluorescencemonitored PCR was performed with the Thermal Cycler Dice Real-time System TP800 (TaKaRa) using TaqMan PCR Master Mix Reagents $2 \times$ and TaqMan Gene Expression Assays of primers 20x, according to the manufacturer's instructions. The data was analyzed using Thermal Cycler Dice Real-time System software (TaKaRa) and the comparative $\mathrm{C}_{\mathrm{t}}$ method $\left(2 \Delta \Delta \mathrm{C}_{\mathrm{t}}\right)$ was used to quantify gene expression levels according to the manufacturer's instructions. The results were expressed relative to levels of the GAPDH transcript used as an internal control. All primers used in this analysis list in Table 2.

\section{Count the number of epididymal spermatozoa}

The epididymal spermatozoa count were determined from both left and right epididymis of mice at day 0 $(n=5)$, day $60(n=5)$, day $120(n=20)$, and day $150(n=$ 5 ) in four groups. Briefly, the epididymides were cut into six pieces and gently pipetted in PBS. The pieces were gently stirred with a pipette, and then passed through a stainless-steel mesh. The epididymal spermatozoa were harvested by centrifugation at $400 \times g$ for $10 \mathrm{~min}$ and resuspended in $5 \mathrm{ml}$ of PBS after washing three times with PBS. The number of epididymal spermatozoa was counted on hemocytometer.

\section{Statistical analysis}

To analyze the differences, ANOVA was used. Statistical significance level was considered at $p$-value $<0.05$.

\section{Results}

TJ107 recovers reproductive functions in TBI mice until day 150 but not day 120

The testicular weight, epididymal spermatozoa, and fertility of mice after the treatment period in four groups are summarized in Table 3. At day 60, in Group C there was significant decreases in body weight, absolute and relative testicular weights, and epididymal spermatozoa counts when compared to those in the Group A. Further, a marginal recovery in body weight and all reproductive parameters were observed at day 120 , but on day 150 further decreases in all parameters were noted in this group. Based on histological examinations of the testes (Fig. 2a-d), some atrophic seminiferous tubules with disrupted spermatogenesis were recognized in the testes (Fig. 2c). In sharp contrast, in the Group D, significant recoveries in body weight, epididymal spermatozoa counts, and fertility rates were observed at day 150 , although absolute and relative testicular weights did not reach control levels (Table 3). All stages of germinal epithelium maturation, from spermatogonia to spermatozoa 
Table 2 Primers used for real-time RT-PCR

\begin{tabular}{|c|c|c|}
\hline gene & Forward Primer( $\left.5^{\prime}-3^{\prime}\right)$ & Reverse Primer(5'-3') \\
\hline caspase8 & TTGAACAATGAGATCCCCAAA & $\begin{array}{l}\text { CCATTTCTACAAAAATTT } \\
\text { CAAGCAG }\end{array}$ \\
\hline claudin-3 & TCTCCCAGCCTACGGAGTTA & CAGTTCCCATCTCTCGCTTC \\
\hline claudin-11 & $\begin{array}{l}\text { TCACAACGTCCACCAATG } \\
\text { ACTG }\end{array}$ & $\begin{array}{l}\text { GGCACATACAGGAAACCA } \\
\text { GATG }\end{array}$ \\
\hline Fas & GCAGACATGCTGTGGATCTGG & $\begin{array}{l}\text { TCACAGCCAGGAGA } \\
\text { ATCGCAG }\end{array}$ \\
\hline FasL & $\begin{array}{l}\text { TCCAGGGTGGGTCTACTT } \\
\text { ACTAC }\end{array}$ & СCCTCTTACTTCTCCGTTAGGA \\
\hline GAPDH & TGTGTCCGTCGTGGATCTGA & TTGCTGTTGAAGTCGCAGGAG \\
\hline Ki67 & $\begin{array}{l}\text { GCTGTCCTCAAGACAATC } \\
\text { ATCA }\end{array}$ & GGCGTTATCCCAGGAGACT \\
\hline occludin & CTTCTGCTTCATCGCTTCC & CTTGCCCTITCCTGCTTC \\
\hline $20-1$ & ACAAACAGCCCTACCAACC & ССАТССТСАТСТTСАТСТTСТTC \\
\hline $\mathrm{ZO}-2$ & GTTITCTTCGTCCTAGTCCC & CATCCATCCCTTCCATCTTTC \\
\hline
\end{tabular}

were shown in group D in testicular sections showing many normal-appearing seminiferous tubules (Fig. 2d).

TJ107 normalizes proliferation and apoptosis in the testes of $6 \mathrm{~Gy}$-treated mice

Next, at day 120, we detected markers of proliferation (Fig. 3a-e) and apoptosis (Fig. 4a-e) in the testes of each group. Few seminiferous tubules with proliferating spermatogonia were detected (Fig. 3c), and increased apoptotic germ cells were detected in atrophic seminiferous tubules (Fig. 4c) were seen in Group C. In the Group D, not only proliferating spermatogonia (Fig. 3d) but also apoptotic germ cells (Fig. 4d) could be detected in the seminiferous tubules, similar to that observed in the Group A (Figs. 3a and 4a). Additionally, the expression of proliferation-related (Ki67) and apoptotic (Fas, FasL, and caspase8) genes in the testicular tissues of each group were examined. Results showed that the expression of Ki67 was significantly decreased only in the Group C, but not in the other three groups (Fig. 3e). In group $\mathrm{C}$, the expression of Fas and caspase8 were significantly increased but not in the other groups (Fig. 4e). FasL level was not significantly altered among the four groups.

\section{The production of serum anti-germ cell antibodies in 6Gy-treated mice is suppressed by TJ107}

In group $C$ upon assessing the reaction of sera with normal frozen seminiferous tubule section, anti-germ cell antibodies were detected (Fig. 5a-d). Serum autoantibodies preferentially reacted with mature spermatids and spermatozoa in Group C; concurrently, faint immunostaining was detected in the spermatogonia and immature spermatids. Furthermore, to analyze blood-testis-barrier (BTB) function, the expressions of testicular tight junction markers were evaluated by

Table 3 Effect of TBI (6Gy) and TJ107 on testicular weight, epididymal spermatozoa, and fertility in male mice

\begin{tabular}{|c|c|c|c|c|c|}
\hline & & Group A & Group B & Group C & Group D \\
\hline \multirow[t]{4}{*}{ Body weight (g) } & Day 0 & $17.314 \pm 0.862$ & $17.314 \pm 0.862$ & $17.314 \pm 0.862$ & $17.314 \pm 0.862$ \\
\hline & Day 60 & $28.501 \pm 1.080$ & $28.501 \pm 1.080$ & $25.425 \pm 1.903^{*}$ & $25.425 \pm 1.903^{*}$ \\
\hline & Day 120 & $31.779 \pm 2.347$ & $31.932 \pm 3.021$ & $28.434 \pm 2.669^{*}$ & $28.723 \pm 2.289^{*}$ \\
\hline & Day 150 & $33.448 \pm 1.118$ & $35.250 \pm 3.442$ & $27.662 \pm 1.360^{*}$ & $30.060 \pm 2.173$ \\
\hline \multirow[t]{4}{*}{ Testis weight (g) } & Day 0 & $0.064 \pm 0.004$ & $0.064 \pm 0.004$ & $0.064 \pm 0.004$ & $0.064 \pm 0.004$ \\
\hline & Day 60 & $0.097 \pm 0.003$ & $0.097 \pm 0.003$ & $0.044 \pm 0.003^{*}$ & $0.044 \pm 0.003^{*}$ \\
\hline & Day 120 & $0.098 \pm 0.002$ & $0.102 \pm 0.006$ & $0.063 \pm 0.006^{*}$ & $0.065 \pm 0.004^{*}$ \\
\hline & Day 150 & $0.095 \pm 0.004$ & $0.106 \pm 0.006$ & $0.057 \pm 0.004^{*}$ & $0.069 \pm 0.004^{*}$ \\
\hline \multirow[t]{4}{*}{ Relative testis weight (\%) } & Day 0 & $0.389 \pm 0.028$ & $0.389 \pm 0.028$ & $0.389 \pm 0.028$ & $0.389 \pm 0.028$ \\
\hline & Day 60 & $0.354 \pm 0.013$ & $0.354 \pm 0.013$ & $0.177 \pm 0.013^{*}$ & $0.177 \pm 0.013^{*}$ \\
\hline & Day 120 & $0.312 \pm 0.034$ & $0.315 \pm 0.024$ & $0.211 \pm 0.016^{*}$ & $0.249 \pm 0.806^{*}$ \\
\hline & Day 150 & $0.281 \pm 0.012$ & $0.285 \pm 0.015$ & $0.191 \pm 0.019^{*}$ & $0.225 \pm 0.016$ \\
\hline \multirow[t]{4}{*}{ spermatozoa $\left(\times 10^{5}\right)$} & Day 0 & $13.600 \pm 0.050$ & $13.600 \pm 0.050$ & $13.600 \pm 0.050$ & $13.600 \pm 0.050$ \\
\hline & Day 60 & $18.600 \pm 0.530$ & $18.600 \pm 0.530$ & $3.935 \pm 0.148^{*}$ & $3.935 \pm 0.148^{*}$ \\
\hline & Day 120 & $19.585 \pm 1.903$ & $26.332 \pm 2.790^{*}$ & $3.987 \pm 0.588^{*}$ & $8.860 \pm 0.391^{*}$ \\
\hline & Day 150 & $22.560 \pm 0.533$ & $25.810 \pm 0.871^{*}$ & $3.515 \pm 0.548^{*}$ & $23.732 \pm 2.041^{\#}$ \\
\hline Rate of Fertility & Day 150 & $100 \%(10 / 10)$ & $100 \%(10 / 10)$ & $40 \%(4 / 10)^{*}$ & $100 \%(10 / 10)^{\#}$ \\
\hline
\end{tabular}

Data are presented as the mean \pm standard deviation. Relative testis weight was calculated as a percentage by dividing the combined weight of both testes in milligrams by the body weight in grams. ${ }^{*} p<0.05$ vs. Group A; ${ }^{\#} p<0.05$ vs. Group C 

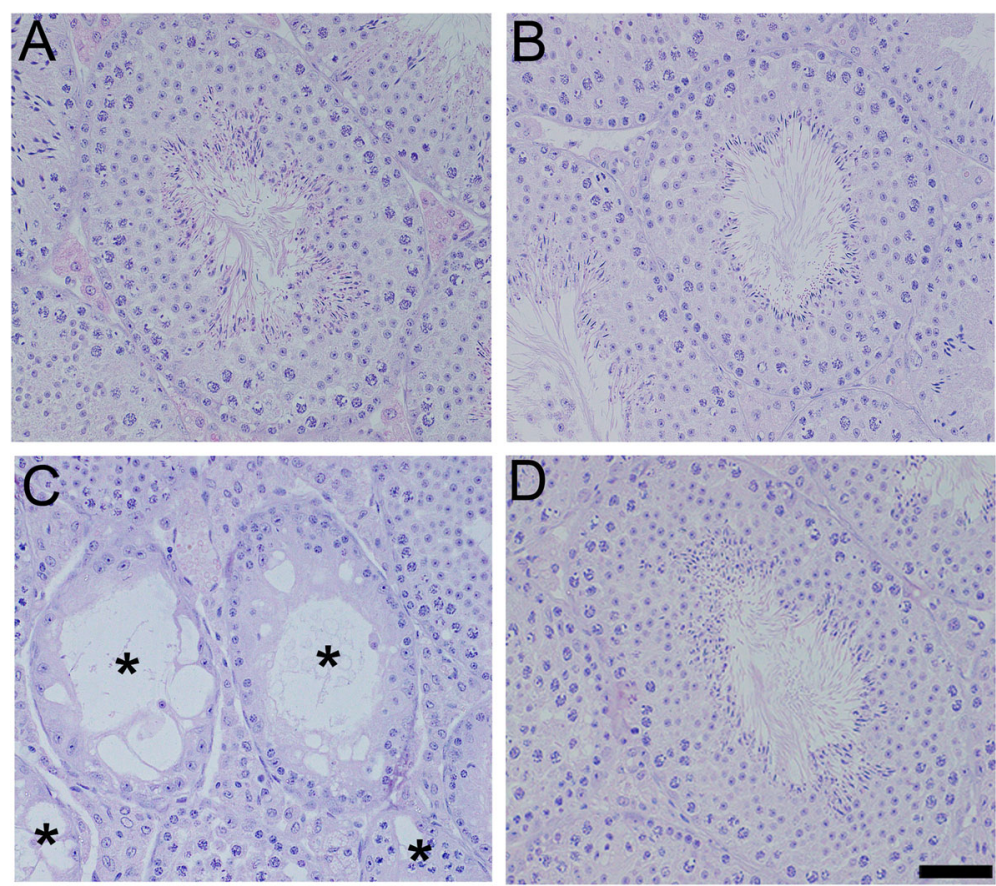

Fig. 2 Effect of TJ107 on testes histology after irradiation. Asterisks indicates the damaged seminiferous tubules with azoospermia in Group C c at day 120. However, in the Group D d, all stages of maturation of the germinal epithelium are seen in normal-appearing seminiferous tubules like in Group A a and Group B b. Bar $=50 \mu \mathrm{m}$

real-time RT-PCR. The mRNA levels of tight junction genes (claudin11, occludin, and ZO1; Fig. 5e) were all significantly increased after TJ107 supplementation. However, claudin3 and ZO2 levels were not significantly altered among the four groups.

\section{Discussion}

To preserve the fertility of young male cancer patients, developing methods to minimize or reverse the gonadal toxicity associated with irradiation and chemotherapy is of great importance. Recently, we demonstrated that

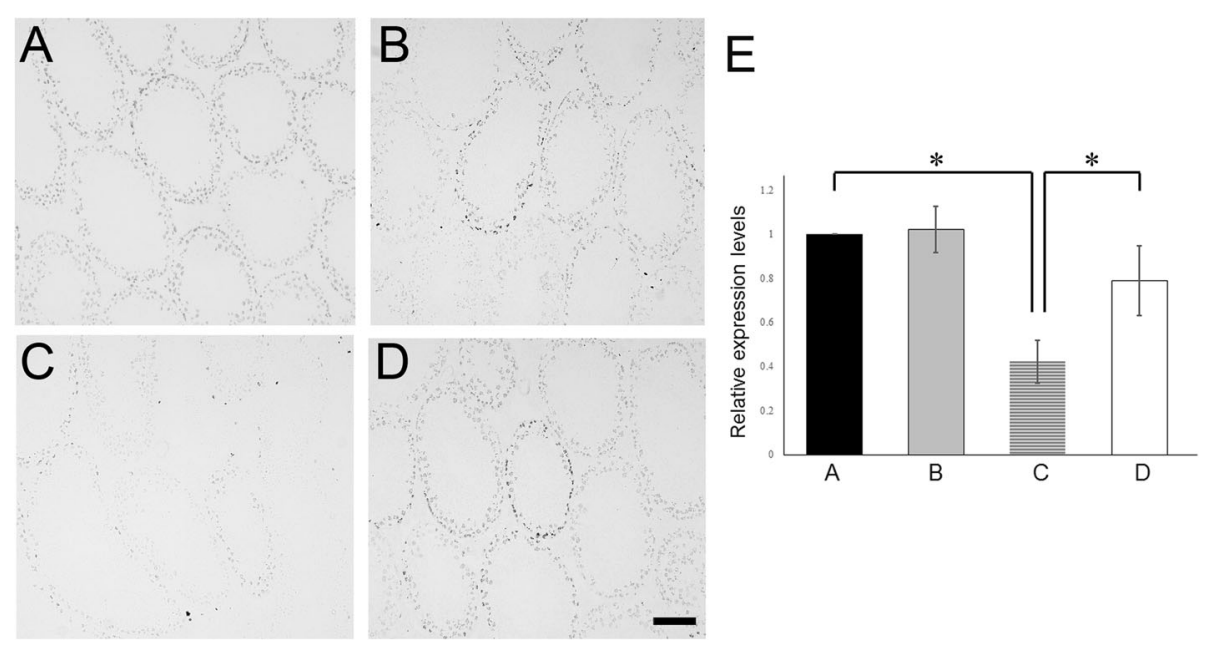

Fig. 3 After irradiation and TJ107 treatment shows proliferating cells in the testes. Samples were assessed at day 120 for each group. Immunohistological detection of Ki67 staining in testicular sections in Group A a, Group B b. Group C c, and Group D d. Ki67-positive nuclei of proliferating spermatogonia are indicated by dark brown spots, which were detected in almost all seminiferous tubules of the Group A a, Group B band Group D d on day 120. In the Group C c few seminiferous tubules with Ki67-positive cells were sporadically observed. Bar $=100 \mu \mathrm{m}$. e Expression of Ki67 mRNA in the mouse testes of each group at 120 days. Calculation of Relative mRNA intensity was done, and the expression in the control group for each point was set to 1. The data are presented as mean \pm standard deviation $(n=10)$. Asterisks indicate $p<0.05$ 

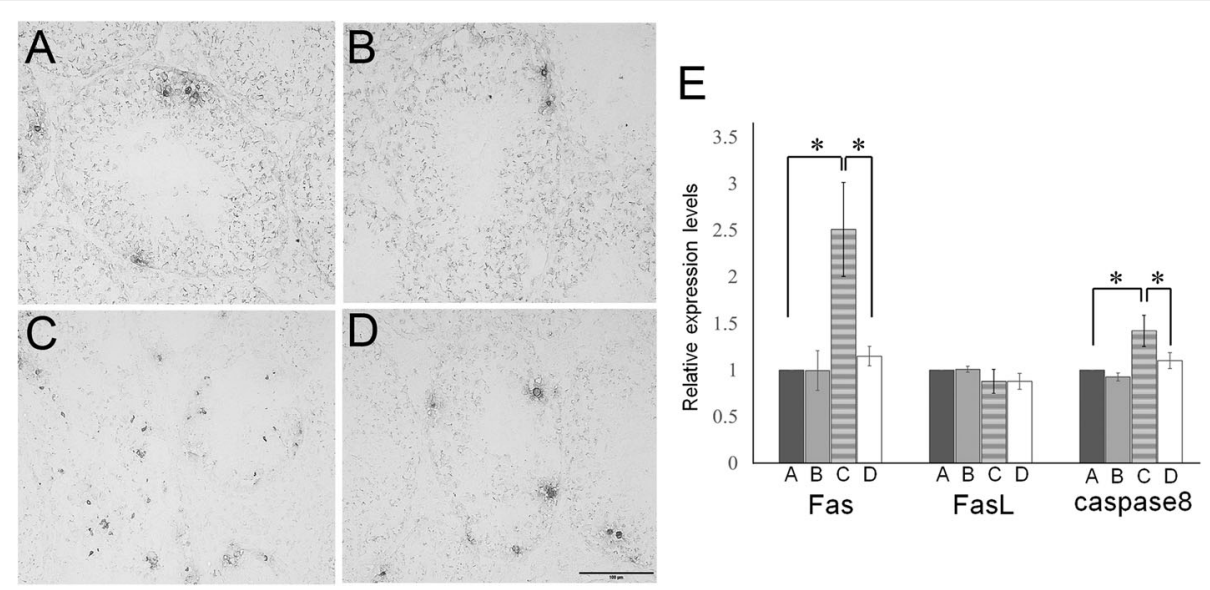

Fig. 4 Detection of apoptotic markers in cells of the testes after irradiation and TJ107 treatment. Spermatogenic cell apoptosis was assessed at day 120 in each group. Group A a, Group B b, Group C c and Group D d histological detection showed TUNEL staining in the testicular sections. Erratic round-shaped black areas in the seminiferous tubules indicate TUNEL-positive cells. Bar $=100 \mu \mathrm{m}$. e Expression of Fas, Fas ligand (FasL), and caspase 8 mRNA in mouse testes of each group at 120 days. Calculation of Relative mRNA intensity was done and the expression in the control group for each point was set to 1. The data are presented as mean \pm standard deviation $(n=10)$. Asterisks indicate $p<0.05$

TJ107, a traditional Japanese medicine, can rescue aspermatogenesis after busulfan treatment in mice [39]. In this study, we evaluated the TJ107efficacy on recovery aspermatogenesis by irradiation. The results showed that disruption of spermatogenesis with a decrease in interSertoli tight junction mRNA levels and a loss of BTB function was induced by 6 Gy of TBI which might be related to the production of anti-germ cell antibodies. However, the spermatogenesis was recovered from TBIinduced injuries with TJ107 administration, based on the enhanced expression of tight junction genes and suppression of anti-germ cell antibody production.

In spite of the presence and persistence of undifferentiated spermatogonia appearing to be blocked from further differentiation, variety of testicular toxicant such as irradiation and alkylating agents can damage seminiferous tubule in rodents. In particular, stimulation of spermatogonial differentiation resulting in spermatogenic progression after cancer treatment is because of the suppression of testosterone and gonadotrophin analogs $[16,44]$. However, multiple side effects and recovery occurs gradually because of hormone-suppression, to enhance endogenous spermatogenic recovery the application of hormone-suppression treatments has so far been successful in clinical trials [16]. Our results from the present study and our previous work demonstrate that supplementation with TJ107, made of natural products with negligible side effects, can rescue injured
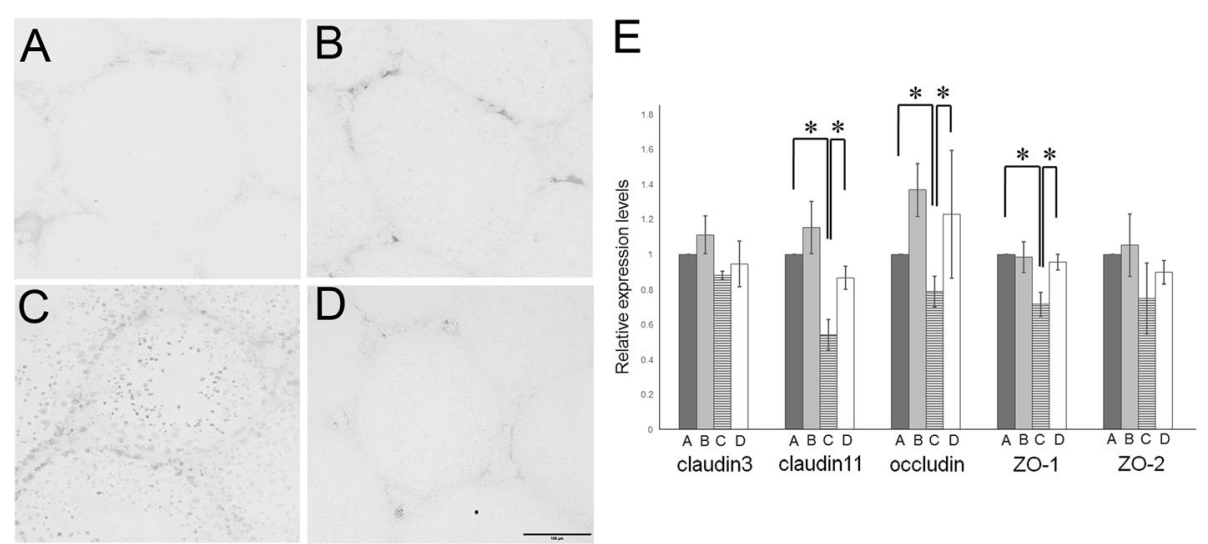

Fig. 5 Serum anti-germ cell antibody levels and testes tight junction markers after irradiation and TJ107 treatment. Diluted sera obtained from Group A a, Group B b, Group C c and Group D d was reacted with Normal frozen sections of seminiferous tubules which was followed by incubation with HRP-conjugated anti-mouse $\mathrm{lgG}$. Bar $=100 \mu \mathrm{m}$. e Changes in the mRNA levels of tight-junction associated markers (claudin3, claudin 11, occludin, ZO1, and ZO2) in the mouse testes of each group at 120 days. Calculation of Relative mRNA intensity was done and the expression in the control group for each point was set to 1. The data are presented as mean \pm standard deviation $(n=10)$. Asterisks indicate $p<0.05$ 
reproductive function after not only busulfan but also irradiation treatment.

In these our two studies, we particularly noted that TJ107 in response to busulfan- and irradiation-induced aspermatogenesis has a different therapeutic mechanism. Busulfan-treatment from day 60 to 120 was found to progressively decrease the weight of the testes and the epididymal sperm count, whereas at day 120 after busulfan-treatment TJ107 completely rescued these effects [39]. It was previously shown that busulfaninduced spermatogenic damage results in the upregulation of Toll-like receptor (TLR) 2 and in Sertoli cells and facilitate macrophage infiltration into the testes through TLR4 expression [45]. We first showed that the injured seminiferous epithelium by normalizing macrophage migration can be rescued by $\mathrm{TJ} 107$ and reducing the expression of TLR2 and TLR4 [39]. At day 60, in sharp contrast, significant decrease in weight of the testes and epididymal sperm count was induced by irradiation-treatment; at day 120 we observed marginal recovery, and at day 150 further decrease in all parameters was noted. In contrast to the results observed after busulfan-treatment, supplementation with TJ107 significantly recovered epididymal spermatozoa count and fertility rates until day 150 but not day 120 (Table 3). In the present study, causal examination detected that antigerm cell antibody production and inter-Sertoli tight junction barrier disruption was induced by 6Gy of TBI but this did not cause significant macrophage infiltration into the testes (unpublished observation). TJ107 administration could cure the testicular injuries by reducing the production of serum anti-germ cell antibodies (Fig. $5 \mathrm{~d})$ and recovering the tight junctions, as assessed by the observed normalization of claudin11, occludin, and ZO1 expression (Fig. 5e). It is well known spermatogenesis is destroyed because of busulfan treatment which directly damages the germ cells and Sertoli cells [46], and in our previous busulfan study, we couldn't detect any antigerm cell antibody production (unpublished observation). Accordingly it is also noted that more belated recovery of spermatogenesis is seen in the $6 \mathrm{~Gy}+\mathrm{TJ} 107$ group (day 150) when compared to that in busulfan+TJ107 group (day 120) [39], it can be surmised that autoimmune reaction against germ cells is may affect the delayed recovery of spermatogenesis after irradiation damage to germ cells.

It is well known that BTB is a physical barrier composed of tight junctions between adjacent Sertoli cells and anti-sperm antibody production is enhanced by increase in BTB permeability which causes infertility in males [47-49]. Critical components of the BTB include the integral membrane proteins claudin-11 $[47,48]$, occluding $[50,51]$, and the adaptor protein $\mathrm{ZO}-1[52,53]$ of the tight junction and some reports have shown that with a decrease in ZO-1 and occluding occurs because irradiation-induced BTB disruption $[54,55]$. In the present study, with respect to BTB integrity the contribution of claudin, occludin, and ZO-1 (Fig. 5e) was determined in a single dose. It is found that depending on the recovery of the above disorganized tight junctions TBI-induced aspermatogenesis and the recovery of spermatogenesis (Fig. 5e).

Recently, male reproductive functions are widely improved through phytotherapeutic approaches [56]. Tribulus (Tribulus terrestris L., Zygophyllaceae) is the main phytotherapics which is promoted to increase testosterone and improve sperm characteristics in humans [5760], long Jack (Eurycoma longifolia Jack, Simaroubaceae) [61, 62], fineleaf fumitory (Fumaria parviflora Lam. Ranunculales) [11]., Onion (Allium cepa L. Amaryllidaceae) [63] and black seeds (Nigella sativa L., Ranunculaceae) $[64,65]$. Although, all these evidences based on the therapeutic effects of herbal medicine on male infertility are on animal models and spermatogenic effect on human and its little clinical attestation is yet to be investigated. Thus, we have proposed clinical trial determine the TJ107 effect on reproductive function of oncologic male patients.

We will examine the effects of the other traditional Japanese medicine such as Hachimijiogan and Hochuekkito on oncologic aspermatogenesis and evaluate the efficacy of polyherbal formulation for improving fertility after cancer treatment in next experiments.

\section{Conclusions}

Our studies demonstrated that impaired reproductive function induced by cancer treatments including chemotherapy and radiotherapy related with the different immune-pathophysiological conditions can be cured by TJ107; therefore, we conclude that the administration of TJ107 is potentially useful for male cancer patients. In future experiments, the effects of the other traditional Japanese medicines such as Hachimijiogan and Hochuekkito, which have been routinely administered to patients with male infertility, on cancer treatmentsinduced testicular injuries will be examined.

\section{Abbreviations \\ BTB: blood-testis-barrier; TBl: total body irradiation; TJ107: Goshajinkigan; TLR: Toll-like receptor}

\section{Acknowledgments}

Gosha-jinki-gan extract was manufactured by Tsumura \& Co. (Tokyo, Japan).

\section{Authors' contributions}

Experiments were designed by $\mathrm{NQ}$, and $\mathrm{MI}$. Execution were performed by $\mathrm{KT}$, $\mathrm{KN}, \mathrm{YH}, \mathrm{NQ}$ and YO. Histological and histopathological analyses were

performed by $\mathrm{KT}, \mathrm{MK}$, and NQ. Statistical analyses were performed by SH and SH. NQ drafted the original manuscript and discussed with MI. Secretarial and technical assistance were performed by NH, HT, KS and KS. All authors critically reviewed and revised the manuscript and approved the final version. 


\section{Funding}

The work was supported by a JSPS KAKENHI Grant (C: 15 K08937; 19 K07876) from the Ministry of Education Science Sports and Culture in Japan and Tokai University School of Medicine Research Aid (2018). Author NQ received the funding and the funding had no role in study design, data collection and analysis, preparation of the manuscript and decision to publish.

\section{Availability of data and materials}

The datasets used and analysed during the current study are available from the corresponding author on reasonable request.

\section{Ethics approval and consent to participate}

All experimental protocols in this study were carried out in accordance with the guidelines of the National Institutes of Health and were approved by the Tokyo Medical University Animal Committee.

\section{Consent for publication}

Not applicable.

\section{Competing interests}

All authors have no competing interests to declare.

\section{Author details}

'Department of Anatomy, Tokyo Medical University, Tokyo 160-8402, Japan. ${ }^{2}$ Department of Anatomy, Division of Basic Medical Science, Tokai University School of Medicine, Kanagawa 259-1193, Japan. ${ }^{3}$ Department of Anatomy, Aichi Medical University, 1-1 Yazakokarimata, Nagakute, Aichi 480-1195, Japan

\section{Received: 27 December 2018 Accepted: 2 December 2019}

Published online: 11 December 2019

\section{References}

1. Centola GM, Keller JW, Henzler M, Rubin P. Effect of low-dose testicular irradiation on sperm count and fertility in patients with esticularseminoma. J Androl. 1994;15:608-13. https://doi.org/10.1002/j.1939-4640.1994.tb00507.x.

2. Sanders JE, Hawley J, Levy W, Gooley T, Buckner CD, Deeg HJ, Doney K, Storb R, Sullivan K, Witherspoon R, Appelbaum FR. Pregnancies following high-dose cyclophosphamide with or without high-dose busulfan or totalbody irradiation and bone marrow transplantation. Blood. 1996;87:3045-52. https://doi.org/10.1182/blood.V87.7.3045.bloodjournal8773045.

3. Vergouwen RP, Huiskamp R, Bas RJ, Roepers-Gajadien HL, de Jong FH, van Eerdenburg FJ, Davids JA, de Rooij DG. Radiosensitivity of testicular cells in the prepubertal mouse. Radiat Res. 1994;139:316-26. https://doi.org/10. 2307/3578829

4. Khan S, Adhikari JS, Rizvi MA, Chaudhury NK. Radioprotective potential of melatonin against ${ }^{60} \mathrm{Co} \gamma$-ray-induced testicular injury in male $\mathrm{C} 57 \mathrm{BL} / 6$ mice. J Biomed Sci. 2015;22:61. https://doi.org/10.1186/s12929-015-0156-9.

5. Pino-Lataillade G, Velez de la Calle JF, Viguier-Martinez MC. Influence of germ cells upon Sertoli cells during continuous low-dose rate gammairradiation of adult rats. Mol Cell Endocrinol 1988;58: 51-63. dio:https://doi. org/10.1016/0303-7207(88)90053-6

6. Hasegawa M, Wilson G, Russell LD. Radiation-induced cell death in the mouse testis: relationship to apoptosis. Radiat Res. 1997;147:457-67. https:// doi.org/10.2307/3579503.

7. Silva AM, Correia S, Casalta-Lopes JE, Mamede AC, Cavaco JE, Botelho MF, Socorro S, Maia CJ. The protective effect of regucalcin against radiationinduced damage in testicular cells. Life Sci. 2016;164:31-41. https://doi.org/ 10.1016/j.lfs.2016.09.003.

8. Khan S, Adhikari JS, Rizvi MA, Chaudhury NK. Radioprotective potential of melatonin against Co $\gamma$-ray-induced testicular injury in male C57BL/6 mice. J Biomed Sci. 2015;22:61. https://doi.org/10.1186/s12929-015-0156-9.

9. Cordelli E, Fresegna AM, Leter G, Eleuteri P, Spano M, Villani P. Evaluation of DNA damage in different stages of mouse spermatogenesis after testicular X irradiation. Radiat Res. 2003;160:443-51. https://doi.org/10.1667/RR3053.

10. Ameli M, Hashemi MS, Moghimian M, Schokoohi M. Protective effect of tadalafil and verapamil on testicular function and oxidative stress after torsion/detorsion in adult male rat. Andrologia. 2018;50:e13068. https://doi. org/10.1111/and.13068

11. Shokoohi M, Shoorei H, Soltani M, Abtahi-Eivari SH, Salimnejad R, Moghimian M. Protective effects of the hydroalcoholic extract of Fumaria parviflora on testicular injury induced by torsion/detorsion in adult rat. Andrologia. 2018;50(7):e13047. https://doi.org/10.1111/and.13047.

12. Shoorei H, Khaki A, Khaki AA, Hemmati AA, Moghimian M, Shokoohi M. The ameliorative effect of carvacrol on oxidative stress and germ cell apoptosis in testicular tissue of adult diabetic rats. Biomed Pharmacother. 2019;111: 568-78. https://doi.org/10.1016/j.biopha.2018.12.054.

13. Levine J, Canada A, Stern CJ. Fertility preservation in adolescents and young adults with cancer. J Clin Oncol. 2010;28:4831-41.

14. Yokonishi T, Ogawa T. Cryopreservation of testis tissues and in vitro spermatogenesis. Reprod Med Biol. 2016;15:21-8. https://doi.org/10.1007/ s12522-015-0218-4.

15. Onofre J, Baert Y, Faes K, Goossens E. Cryopreservation of testicular tissue or testicular cell suspensions: a pivotal step in fertility preservation. Hum Reprod Update. 2016;22:744-61. https://doi.org/10.1093/humupd/dmw029.

16. Shetty G, Meistrich ML. Hormonal approaches to preservation and restoration of male fertility after cancer treatment. J Natl Cancer Inst Monogr. 2005;34:36-9. https://doi.org/10.1093/jncimonographs/lgi002.

17. Schally AV, Paz-Bouza JI, Schlosser JV, Karashima T, Debeljuk L, Gandle B, Sampson M. Protective effects of analogs of luteinizing hormone-releasing hormone against x-radiation-induced testicular damage in rats. Proc Natl Acad Sci. 1987:84:851-5. https://doi.org/10.1073/pnas.84.3.851.

18. van Alphen MM, van de Kant HJ, de Rooij DG. Protection from radiationinduced damage of spermatogenesis in the rhesus monkey (Macaca mulatta) by follicle-stimulating hormone. Cancer Res. 1989;49:533-6.

19. Songthaveesin C, Saikhun J, Kitiyanant Y, Pavasuthipaisit K. Radio-protective effect of vitamin $E$ on spermatogenesis in mice exposed to gammairradiation: a flow cytometric study. Asian J Androl. 2004;6:331-6.

20. Mozdarani H, Nazari E. Cytogenetic damage in preimplantation mouse embryos generated after paternal and parental gamma-irradiation and the influence of vitamin C. Reproduction. 2009;137:35-43. https://doi.org/10. 1530/REP-08-0073

21. Bahmanpour S, Vojdan Z, Panjehshahin MR, Hoballah H, Kassas H. Effects of Carthamus tinctorius on semen quality and gonadal hormone levels in partially sterile male rats. Korean J Urol. 2012;53:705. https://doi.org/10.4111/ kju.2012.53.10.705

22. Fedail JS, Ahmed AA, Musa HH, Ismail E, Sifaldin AZ, Musa TH. Gum Arabic improves semen quality and oxidative stress capacity in alloxan induced diabetes rats. Asian Pac J Reprod. 2016;5:434-41. https://doi.org/10.1016/j. apjr.2016.07.014

23. Zang ZJ, Ji SY, Dong W, Zhang YN, Zhang EH, Bin Z. A herbal medicine, saikokaryukotsuboreito, improves serum testosterone levels and affects sexual behavior in old male mice. Aging Male. 2015;18:106-11. https://doi. org/10.3109/13685538.2014.963042.

24. Zhu W, Du Y, Meng H, Dong Y, Li L. A review of traditional pharmacological uses, phytochemistry, and pharmacological activities of Tribulus terrestris. Chem Cent J 2017;11. https://doi.org/10.1186/s13065-017-0289-x.

25. Mohammadi F, Nikzad H, Taherian A, Amini Mahabadi J, Salehi M. Effects of herbal medicine on male infertility. Anatom Sci J. 2013;10(4):3-16.

26. Jo J, Lee SH, Yoon SR, Kim K-II. The effectiveness of Korean herbal medicine in infertile men with poor semen quality: a prospective observational pilot study. Andrologia. 2019:51:e13226. https://doi.org/10.1111/and.13226.

27. Mizuno K, Kono T, Suzuki Y, Miyagi C, Omiya Y, Miyano K, Kase Y, Uezono Y. Goshajinkigan, a traditional Japanese medicine, prevents oxaliplatin-induced acute peripheral neuropathy by suppressing functional alteration of TRP channels in rat. J Pharmacol Sci. 2014;125:91-8. https://doi.org/10.1254/jphs.13244FP.

28. Matsumura $Y$, Yokoyama $Y$, Hirakawa H, Shigeto T, Futagami M, Mizunuma $H$. The prophylactic effects of a traditional Japanese medicine, goshajinkigan, on paclitaxel-induced peripheral neuropathy and its mechanism of action. Mol Pain. 2014;10:61. https://doi.org/10. 1186/1744-8069-10-61.

29. Yagi H, Sato R, Nishio $K$, Arai G, Soh S, Okada H. Clinical efficacy and tolerability of two Japanese traditional herbal medicines, Hachimi-jiogan and Gosha-jinki-gan, for lower urinary tract symptoms with cold sensitivity. J Tradit Complement Med. 2015;5:258-61. https://doi.org/10. 1016/j.jtcme.2015.03.010.

30. Kono T, Suzuki $Y$, Mizuno K, Miyagi C, Omiya $Y$, Sekine $H$, Mizuhara $Y$ Miyano K, Kase Y, Uezono Y. Preventive effect of oral goshajinkigan on chronic oxaliplatin-induced hypoesthesia in rats. Sci Rep. 2015;5:16078. https://doi.org/10.1038/srep16078.

31. Kishida Y, Kagawa S, Arimitsu J, Nakanishi M, Otsuka S, Yoshikawa H Hagihara K. Go-sha-jinki-Gan (GJG), a traditional Japanese herbal medicine, 
protects against sarcopenia in senescence-accelerated mice. Phytomedicine. 2015;22:16-22. https://doi.org/10.1016/j.phymed.2014.11.005.

32. Nakanishi M, Nakae A, Kishida Y, Baba K, Sakashita N, Shibat M, Yoshikawa H, Hagihara K. Go-sha-jinki-Gan (GJG) ameliorates allodynia in chronic constriction injury-model mice via suppression of TNF-a expression in the spinal cord. Mol Pain 2016;12. https://doi.org/10.1177/1744806916656382.

33. Liu CL, Cheng L, Ko CH, Wong CW, Cheng WH, Cheung DW, Leung PC, Fung KP, Bik-San LC. Bioassay-guided isolation of anti-inflammatory components from the root of Rehmannia glutinosa and its underlying mechanism via inhibition of iNOS pathway. J Ethnopharmacol. 2012;143(3): 867-75. https://doi.org/10.1016/j.jep.2012.08.012.

34. Park CH, Noh JS, Kim JH, Tanaka T, Zhao Q, Matsumoto K, Shibahara N, Yokozawa T. Evaluation of morroniside, iridoid glycoside from Corni Fructus, on diabetes-induced alterations such as oxidative stress, inflammation, and apoptosis in the liver of type 2 diabetic db/db mice. Biol Pharm Bull. 2011; 34:1559-65. https://doi.org/10.1248/bpb.34.1559.

35. Chiu CS, Deng JS, Chang HY, Chen YC, Lee MM, Hou WC, Lee CY, Huang SS, Huang GJ. Antioxidant and anti-inflammatory properties of Taiwanese yam (Dioscorea japonica Thunb. var. pseudojaponica (Hayata) Yamam.) and its reference compounds. Food Chem. 2013;141:1087-96. https://doi.org/10. 1016/j.foodchem.2013.04.031.

36. Fu PK, Yang CY, Tsai TH, Hsieh CL. Moutan cortex radicis improves lipopolysaccharide-induced acute lung injury in rats through antiinflammation. Phytomedicine. 2012;19:1206-15. https://doi.org/10.1016/j. phymed.2012.07.013

37. Kubo M, Ma S, Wu J, Matsuda H. Anti-inflammatory activities of 70\% methanolic extract from Cinnamomi Cortex. Biol Pharm Bull. 1996;19:10415. https://doi.org/10.1248/bpb.19.1041.

38. Liao JC, Deng JS, Chiu CS, Hou WC, Huang SS, Shie PH, Huang GJ. Antiinflammatory activities of Cinnamomum cassia constituents in vitro and in vivo. Evid Based Complement Alternat Med. 2012;2012:429320. https:// doi.org/10.1155/2012/429320.

39. Qu N, Kuramasu M, Hirayanagi Y, Nagahori K, Hayashi S, Ogawa Y, Terayama H, Suyama K, Naito M, Sakabe K, Itoh M. Gosha-Jinki-Gan recovers spermatogenesis in mice with busulfan-induced aspermatogenesis. Int J Mol Sci. 2018;19(pii):E2606. https://doi.org/10.3390/ijms19092606.

40. Hirai S, Hatayama N, Naito M, Nagahori K, Kawata S, Hayashi S, Qu N, Terayama H, Shoji S, Itoh M. Pathological effect of arterial ischaemia and venous congestion on rat testes. Sci Rep. 2017;7(1):5422. https://doi.org/10 1038/s41598-017-05880-2.

41. Qu N, Terayama H, Hirayanagi Y, Kuramasu M, Ogawa Y, Hayashi S, Hirai S, Naito $\mathrm{M}$, Itoh $\mathrm{M}$. Induction of experimental autoimmune orchitis by immunization with xenogenic testicular germ cells in mice. J Reprod Immunol. 2017;121:11-6. https://doi.org/10.1016/j.jri.2017.04.006.

42. Hirai S, Naito M, Kuramasu M, Ogawa Y, Terayama H, Qu N, Hatayama N, Hayashi S, Itoh M. Low-dose exposure to di-(2-ethylhexyl) phthalate (DEHP) increases susceptibility to testicular autoimmunity in mice. Reprod Biol. 2015;15(3):163-71. https://doi.org/10.1016/j.repbio.2015.06.004.

43. Lysiak JJ, Turner SD, Turner TT. Molecular pathway of germ cell apoptosis following ischemia/reperfusion of the rat testis. Biol Reprod. 2000;63:146572. https://doi.org/10.1095/biolreprod63.5.1465.

44. Meistrich ML, Shetty G. Inhibition of spermatogonial differentiation by testosterone. J Andro. 2003;24:135-48. https://doi.org/10.1002/j.19394640.2003.tb02652.x.

45. Zhang X, Wang T, Deng T, Xiong W, Lui P, Li N, Chen Y, Han D. Damaged spermatogenic cells induce inflammatory gene expression in mouse Sertoli cells through the activation of Toll-like receptors 2 and 4 . Mol Cell Endocrinol. 2013;365:162-73. https://doi.org/10.1016/j.mce.2012.10.016.

46. Anand S, Bhartiya D, Sriraman K, Mallick A. Underlying mechanisms that restore spermatogenesis on transplanting healthy niche cells in busulphan treated mouse testis. Stem Cell Rev Rep. 2016;12:682-97. https://doi.org/10. 1007/s12015-016-9685-1. Springer US

47. Wang $C Q$, Cheng CY. A seamless trespass: germ cell migration across the seminiferous epithelium during spermatogenesis. J Cell Biol. 2007;178:54956. https://doi.org/10.1083/jcb.200704061.

48. Meinhardt A, Hedger MP. Immunological, paracrine and endocrine aspects of testicular immune privilege. Mol Cell Endocrinol. 2011;335:60-8. https:// doi.org/10.1016/.mce.2010.03.022

49. Cheng CY, Mruk DD. The blood-testis barrier and its implications for male contraception. Pharmacol Rev. 2012;64:16-64. https://doi.org/10. 1124/pr.110.002790.
50. Morita K, Furuse M, Fujimoto K, Tsukita S. Claudin multigene family encoding four-transmembrane domain protein components of tight junction strands. Proc Natl Acad Sci. 1999;96:511-6. https://doi.org/10. 1073/pnas.96.2.511.

51. Morita K, Sasaki H, Fujimoto K, Furuse M, Tsukita S. Claudin-11/OSP-based tight junction of myelin sheaths in brain and Sertoli cells in testis. J Cell Biol. 1999;145:579-88. https://doi.org/10.1083/jcb.145.3.579.

52. Stevenson BR, Siliciano JD, Mooseker MS, Goodenough DA. Identification of ZO-1: a high molecular weight polypeptide associated with the tight junction (zonula occludens) in a variety of epithelia. J Cell Biol. 1986;103: 755-66. https://doi.org/10.1083/jcb.103.3.755.

53. Fanning $A S$, Jameson $B J$, Jesaitis $L A$, Anderson $J M$. The tight junction protein ZO-1 establishes a link between the transmembrane protein occluding and the actin cytoskeleton. J Biol Chem. 1998;273:29745-53. https://doi.org/10.1074/jbc.273.45.29745.

54. Wang XW, Ding GR, Shi CH, Zeng LH, Liu JY, Li J, Zhao T, Chen YB, Guo GZ. Mechanisms involved in the blood-testis barrier increased permeability induced by EMP. Toxicology. 2010;276:58-63. https://doi. org/10.1016/.jtox.2010.07.003.

55. Son Y, Heo K, Bae MJ, Lee CG, Cho WS, Kim SD, Yang K, Shin IS, Lee MY, Kim JS. Injury to the blood-testis barrier after low-dose-rate chronic radiation exposure in mice. Radiat Prot Dosim. 2015;167:316-20. https://doi. org/10.1093/rpd/ncv270

56. Jiang D, Coscione A, Li L, Zeng BY. Effect of Chinese herbal medicine on male infertility. Int Rev Neurobiol. 2017;135:297-311. https://doi.org/10.1016/ bs.irn.2017.02.014.

57. Bhat R, Karim AA. Tongkat Ali (Eurycoma longifolia Jack): a review on its ethnobotany and pharmacological importance. Fitoterapia. 2010;81:669-79. https://doi.org/10.1016/j.fitote.2010.04.006.

58. Chen CK, Mohamad WMZW, Ooi FK, Ismail SB, Abdullah MR, George A. Supplementation of Eurycoma longifolia Jack extract for 6 weeks does not affect urinary testosterone: epitestosterone ratio, liver and renal functions in male recreational athletes. Int J Prev Med. 2014;5:728-33.

59. Neychev V, Mitev V. Pro-sexual and androgen enhancing effects of Tribulus terrestris L.: fact or fiction. J Ethnopharmacol. 2016;179:345-55. https://doi. org/10.1016/j.jep.2015.12.055

60. Santos HO, Howell S, Teixeira FJ. Beyond Tribulus (Tribulus terrestris L.): The effects of phytotherapics on testosterone, sperm and prostate parameters. J Ethnopharmacol. 2019;235:392-405. https://doi.org/10.1016/j.jep.2019.02.033.

61. Khanijo T, Jiraungkoorskul W. Review ergogenic effect of long Jack, Eurycoma longifolia. Pharmacogn Rev. 2016;10:139-42. https://doi.org/10. 4103/0973-7847.194041.

62. Rehman SU, Choe K, Yoo HH. Review on a traditional herbal medicine, Eurycoma longifolia Jack (Tongkat Ali): its traditional uses, chemistry, evidence- based pharmacology and toxicology. Molecules. 2016;21:331. https://doi.org/10.3390/molecules21030331.

63. Shokoohi M, Madarek EOS, Khaki A, Shoorei H, Khaki AA, Soltani M, Ainehchi $N$. Investigating the effects of onion juice on male fertility factors and pregnancy rate after testicular torsion/detorsion by intrauterine insemination method. Int J WHR Sci. 2018:4:499-505. https://doi.org/10. 15296/ijwhr.2018.82.

64. Mahdavi R, Heshmati J, Namazi N. Effects of black seeds (Nigella sativa) on male infertility: a systematic review. J Herb Med. 2015;5:133-9. https://doi. org/10.1016/j.hermed.2015.03.002.

65. Talbott SM, Talbott JA, George A, Pugh M. Effect of Tongkat Ali on stress hormones and psychological mood state in moderately stressed subjects. J Int Soc Sports Nutr. 2013;10:28. https://doi.org/10.1186/1550-2783-10-28.

\section{Publisher's Note}

Springer Nature remains neutral with regard to jurisdictional claims in published maps and institutional affiliations. 